\author{
Sanjay Bansode ${ }^{1,2}$, Ramesh Kapadnis ${ }^{1,2}$, Vasant Wagh', \\ Sampat $\mathrm{Kale}^{3}$ and Habib Pathan ${ }^{1}$
}

\title{
COMPARATIVE STUDIES ON PHYSICO-CHEMICAL PROPERTIES OF IN DIUM SULFIDE FILMS DEPOSITED UNDER DIFFERENT DEPOSITION CONDITIONS BY CHEMICAL BATH DEPOSITION
}

\author{
${ }^{1}$ Advance Physics Laboratory, Department of Physics, University of Pune, India; \\ pathan@physics.unipune.ac.in \\ ${ }^{2}$ K.V.N.Naik College of Arts Science and Commerce, Nashik, India \\ ${ }^{3}$ Arts Science and Commerce College, Dindori, Nashik, India
}

Received: March 25, 2014 / Revised: June 04, 2014 / Accepted: September 10, 2014

(C) Bansode S., Kapadnis R., Wagh V., Kale S., Pathan H., 2014

\begin{abstract}
Indium sulfide films have been deposited using chemical bath deposition onto glass and indium tin oxide (ITO) coated glass substrates. The influences of different deposition parameters viz. substrate and $\mathrm{pH}$ have been studied. The films were characterized by different techniques with respect to their crystal structure, surface morphology and compositional property by means of X-ray diffraction, scanning electron microscopy, energy dispersive spectroscopy and optical absorption. X-ray diffraction studies revealed amorphous nature of the films. The scanning electron microscopy of deposited indium sulfide film on ITO coated glass substrate shows random orientation of grains where as those on glass substrates show dumbbell shape. Optical absorption study revealed that band gap varies from 2.29 to $2.79 \mathrm{eV}$ for the deposited film.
\end{abstract}

Keywords: chemical bath deposition, optical properties, structural property, indium sulfide.

\section{Introduction}

Indium sulfide is an important material for the optoelectronic and photovoltaic applications due to its suitable band gap [1]. In CuInGaSe 2 based solar cell, $\mathrm{CdS}$ is used as a buffer layer. Due to hazardous nature of $\mathrm{CdS}$ an alternative material is being explored for buffer layer. $\operatorname{In}_{2} \mathrm{~S}_{3}$ is one probable replacement of $\mathrm{CdS}[2,3]$. At atmospheric pressure it exists in different forms $(\alpha, \beta$ and $\gamma)$. A defect cubic structure $\alpha-\operatorname{In}_{2} \mathrm{~S}_{3}$, a defect spinal $\beta$ - $\operatorname{In}_{2} \mathrm{~S}_{3}$ and layered structure $\gamma-\operatorname{In}_{2} \mathrm{~S}_{3}$ are the possible forms of $\operatorname{In}_{2} \mathrm{~S}_{3}[4,5]$.

Indium sulfide could be prepared using different methods, such as chemical vapor deposition [6], atomic layer epitaxy [7], SILAR [8] and chemical bath deposition
[9]. Chemical bath deposition (CBD) is simple and lowcost method, which can be used for deposition of large area thin films. In this method various substrates can be used, such as metal, semiconductor or insulator. Optical band gap $(E g)$ of indium sulfide films deposited by using chemical bath deposition was found to be $2.75 \mathrm{eV}$ [10].

In this work indium sulfide films were deposited by means of CBD. The authors reported optical, surface morphological and compositional study of indium sulfide films by means of scanning electron microscope, X-ray diffraction, energy dispersive spectroscopy, and optical absorption of films deposited under different deposition conditions.

\section{Experimental}

All chemicals used in this work were commercially available, and used without further purification. The deposition was carried out onto glass substrate and ITO coated glass substrates by sequential addition of indium sulphate, $80 \%$ hydrazine hydrate, thioacetamide, and triethanolamine. Deposition of indium sulfide was carried out in acidic bath. The solution was prepared in $25 \mathrm{ml}$ beaker by sequential addition of $5 \mathrm{ml}$ of $0.1 \mathrm{M}$ indium sulphate and $0.1 \mathrm{ml}$ of $0.15 \mathrm{M}$ triethanolamine. The solution was stirred well. Then under the continuous stirring $0.2 \mathrm{ml}$ of hydrazine hydrate was added and $5 \mathrm{ml}$ of $0.1 \mathrm{M}$ thioacetamide solution was mixed to the bath. Acetic acid was added dropwise to the bath so that the initial $\mathrm{pH}$ of the solution was about 4 . Clean substrates viz. glass and ITO coated glass were placed vertically in reactive solution separately. With same deposition parameter $\mathrm{pH}$ of the solution was adjusted about 9 . 
Substrates were placed in reactive solution. Deposition was carried out at room temperature for about $120 \mathrm{~h}$. Deposited indium sulfide films were yellowish in color. The structural properties of the deposited films were determined by X-ray diffraction using X-ray diffractometer (XRD RigakuD/max-2400 with $\mathrm{Cu}-\mathrm{k} \alpha=$ $0.154 \mathrm{~nm}$ ). Surface morphology was studied by scanning electron microscope (SEM) JOEL JSM6360 equipment. Film composition was determined by energy dispersive spectroscopy (EDS). The optical absorption measurements are carried out in the range of 350-900 nm using UV-VIS spectrophotometer (Hitachi-330, Japan).

\section{Results and Discussion}

\subsection{X-ray Diffraction}

XRD pattern (not shown in Fig.) of the films obtained by chemical bath deposition was carried out in

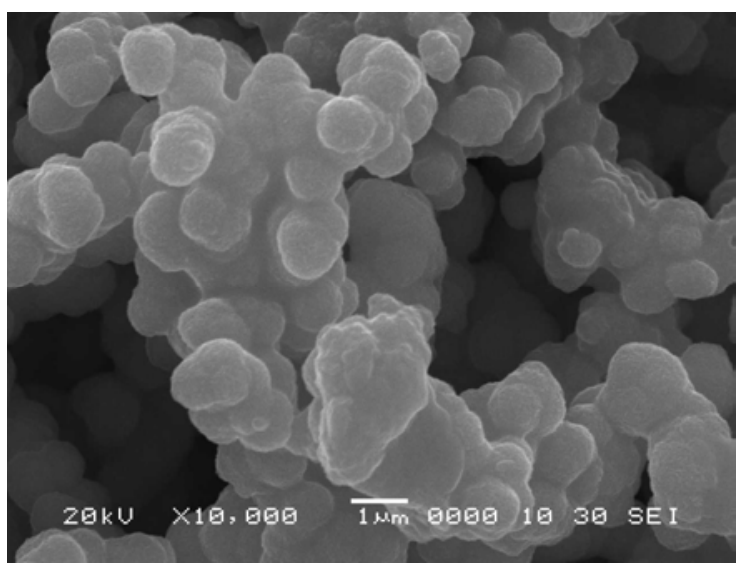

a)

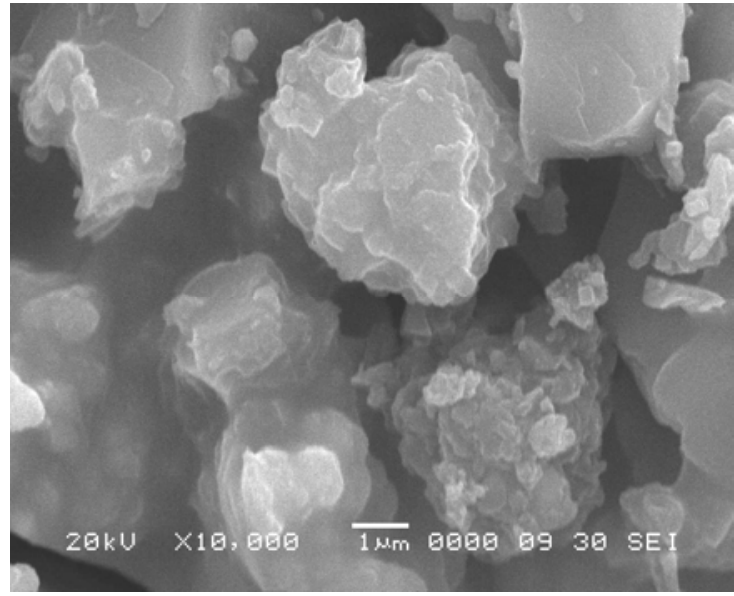

c) the range of diffraction angle of $2 \theta$ between 20 and $80 . \mathrm{X}$ ray pattern of indium sulfide films deposited onto glass as well as onto ITO coated glass substrate at room temperature shows that deposited films are amorphous in nature. C. Lokhande et al. [10] reported that indium sulfide thin films deposited on glass substrate at $323 \mathrm{~K}$ showed amorphous nature while onto FTO coated glass substrate it showed polycrystalline nature. Energy dispersive X-ray analysis shows that the ratio of atomic percentage of In to $\mathrm{S}$ was about $46: 58$ for the films deposited at $\mathrm{pH} 4$. However the ratio of atomic percentage of In to $\mathrm{S}$ was $36: 63$ for the films deposited at $\mathrm{pH} \mathrm{9,}$ which confirms the formation of indium sulfide films.

\subsection{SEM}

SEM images of the films deposited with different $\mathrm{pH}$ onto various substrates at room temperature are shown in Fig. 1.

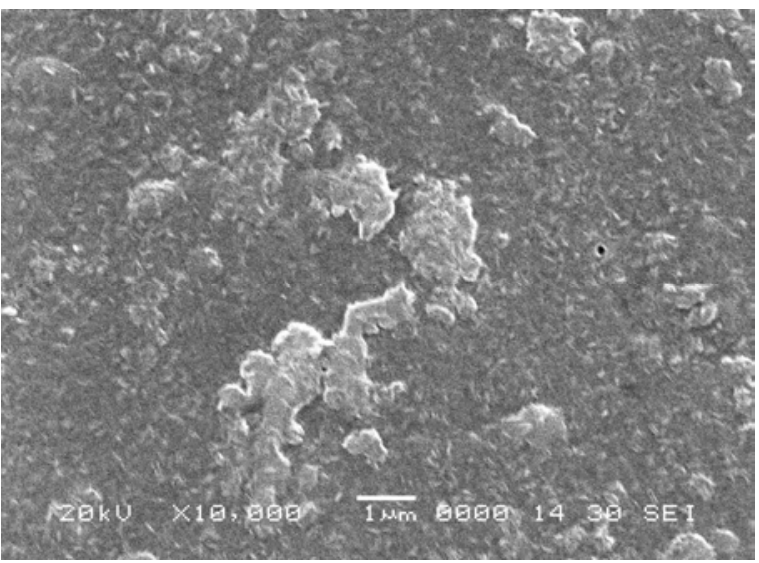

b)

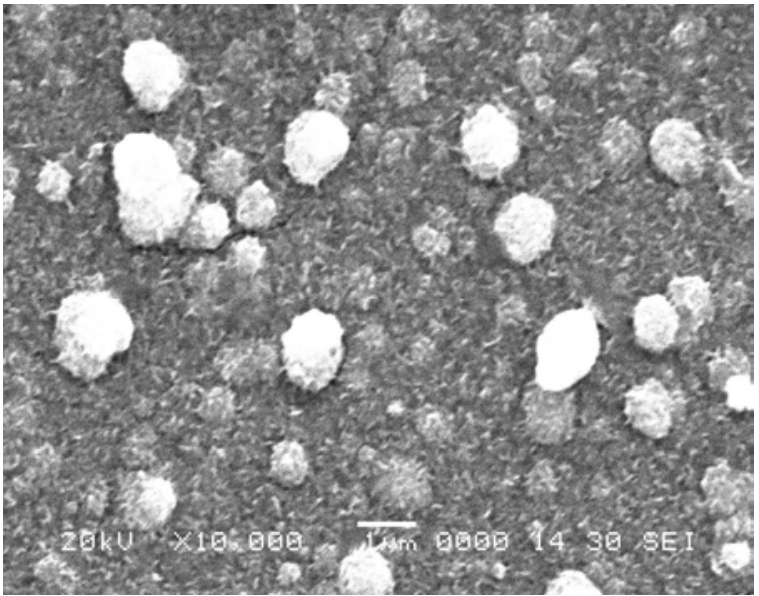

d)

Fig. 1. SEM images of indium sulfide thin film deposited in acidic bath (a) onto glass substrates (b) onto ITO substrates; in basic bath (c) and onto glass substrates (d) onto ITO substrates 
SEM studies showed that surface morphology changes for the films deposited on various substrate with different $\mathrm{pH}$ values. Fig. 1a shows dumbbell shape clusters. Fig. 1b shows that deposited films have uniform coverage of substrate with no cracks. Surface shows grains of different shape. Fig. 1c shows that there is dramatic change in the morphologies of the films growth. It consists of plate-like particles with random orientation. Fig. 1d shows uniform coverage of grain with an irregular round shape dispersed on the film surface. Hence, it is clear that surface of deposited films on ITO coated glass

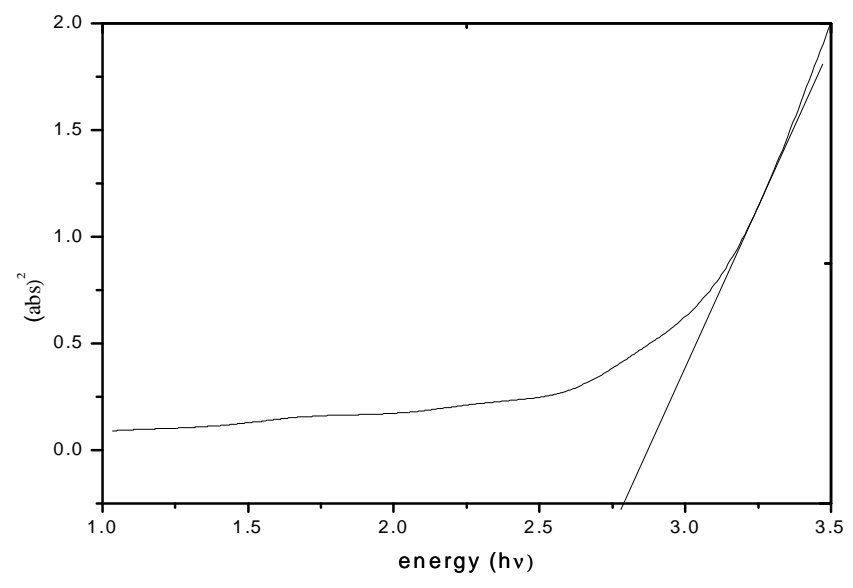

a)

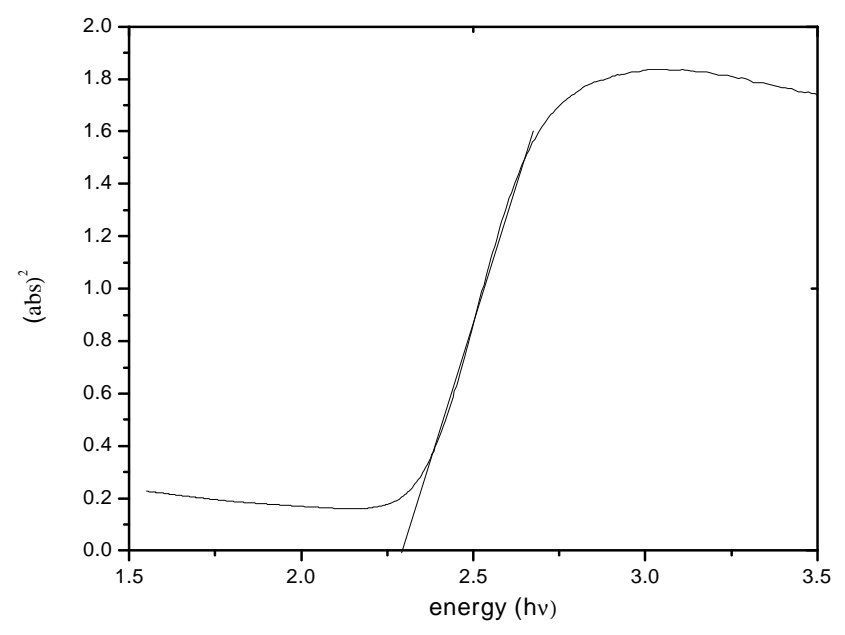

c) substrate becomes dense compared to the surface of deposited films on glass substrate. Growth rate of the film is very slow at room temperature.

\subsection{Optical Properties}

Energy band gap (Eg) of deposited film was determined from their absorption spectra. It has been reported that optical band gap of indium sulfide varied from 2.1 to $2.9 \mathrm{eV}$ with several phases [10]. To determine the optical band gap of deposited indium sulfide thin film plot of $(\mathrm{abs})^{2} v s$. (hv) has been plotted and shown in Fig. 2.

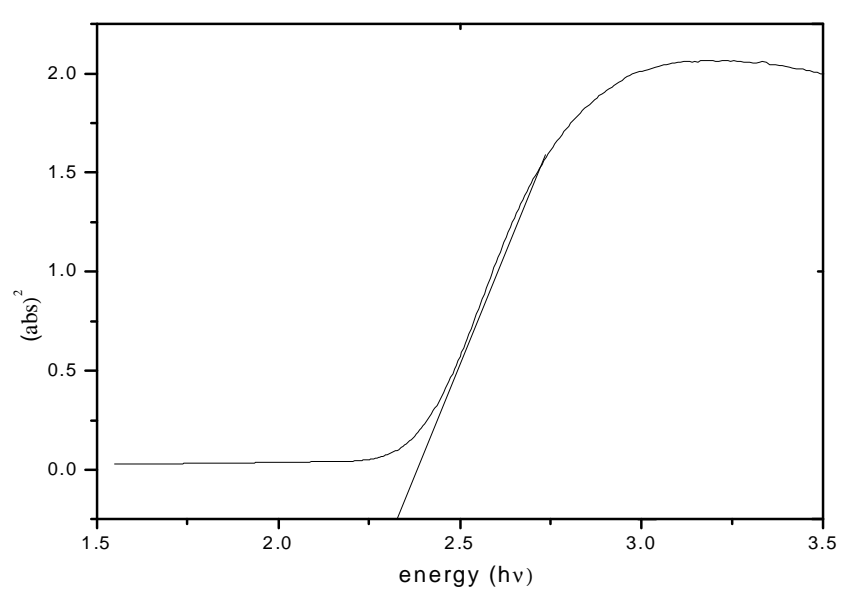

b)

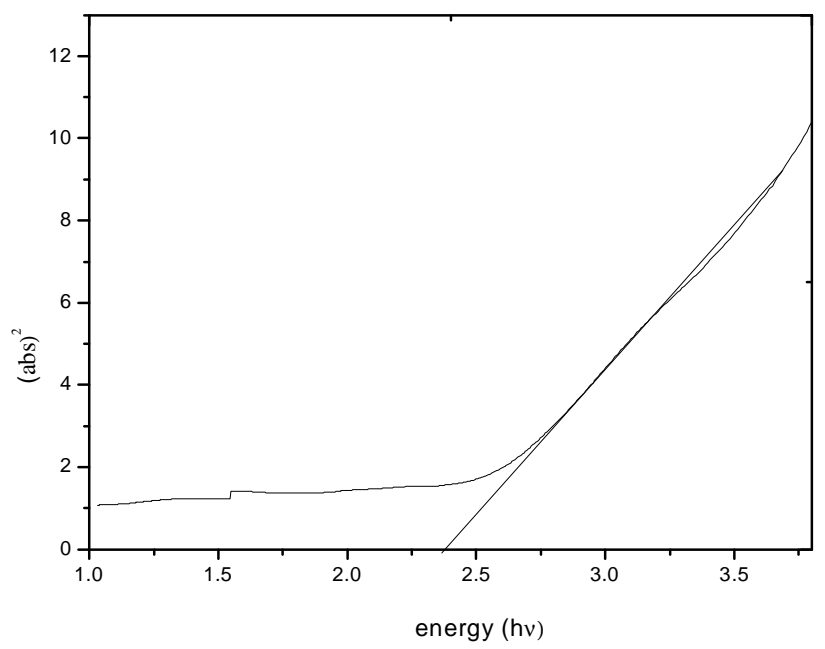

d)

Fig. 2. Plot of $(\alpha h v)^{2} v s$. (hv) for indium sulfide thin film deposited: at $\mathrm{pH} 4$ (a) onto glass substrates (b) onto ITO substrates; at $\mathrm{pH} 9$ (c) onto glass substrates (d) onto ITO substrates

Band gap values of indium sulfide thin films

\begin{tabular}{|c|c|c|c|}
\hline \multicolumn{2}{|c|}{ Films deposited on glass substrate } & \multicolumn{2}{c|}{ Films deposited on ITO coated glass substrate } \\
\hline acidic bath & basic bath & acidic bath & basic bath \\
\hline $2.79 \mathrm{eV}$ & $2.40 \mathrm{eV}$ & $2.32 \mathrm{eV}$ & $2.29 \mathrm{eV}$ \\
\hline
\end{tabular}


Fig. 2a shows that the band gap was $2.79 \mathrm{eV}$ for the film deposited on glass substrate at $\mathrm{pH} 4$. Band gap $2.32 \mathrm{eV}$ estimated for the films deposited on ITO coated glass substrate for the same $\mathrm{pH}$ is shown in Fig. 2b. This value is very close to the direct energy band gap determined in amorphous $\operatorname{In}_{2} \mathrm{~S}_{3}$ film deposited on glass substrate by CBD [10]. Figs. 2c and $2 \mathrm{~d}$ show the plot for deposited thin film at $\mathrm{pH} 9$ on glass and ITO substrate, respectively. The estimated band gap was $2.40 \mathrm{eV}$ for the film deposited on the glass substrate and $2.29 \mathrm{eV}$ for the film deposited on ITO substrate. This value is close to the energy band gap 2.2-2.4 eV reported by M. CalixtoRodriguez et al. [12]. As shown in the Table band gap value of $2.40-2.79 \mathrm{eV}$ for the indium sulfide films deposited on glass substrate is more than band gap value of $2.32-2.29 \mathrm{eV}$ for the films deposited on ITO coated glass substrate. This may be due to the porosity of surface morphology of indium sulfide film deposited on glass substrate.

\section{Conclusions}

In this paper the structural and optical properties of deposited films were reported by changing substrate and $\mathrm{pH}$ values. XRD studies showed the amorphous nature of film. SEM showed the effect of substrate on film growth. From optical studies direct band gap indium sulfide film varies from 2.29 to $2.79 \mathrm{eV}$. Hence optical study shows that the optical properties of the indium sulfide films varied with the change of $\mathrm{pH}$ of precursor bath and the deposing substrate material.

\section{References}

[1] Bhira L. et al.: Phys. Status Solidia, 2000, 181, 427.
[2] Buecheler S., Corica D., Guettler D. et al.: Thin Solid Films, 2009, 517, 2312.

[3] Barreau N.: Solar Energy, 2009, 83, 363.

[4] Diehl R. and Nitsche R.: J. Cryst. Growth, 1975, 28, 306.

[5] Yu S., Shu L., Wu Y. et al.: J. Am. Ceram. Soc., 1999, 82, 457.

[6] Nomura R., Konishi K. and Matsuda H.: Thin Solid Films, 1990, 198, 339.

[7] Asikainen T., Ritala M. and Leskela M.: Appl. Surf. Sci., 1994, 82/83, 122.

[8] Pathan H., Lokhande C., Kulkarni S. et al.: Mat. Res. Bull., 2005, 40, 1018.

[9] Mane R. and Lokhande C.: Mat. Chem. \& Physics, 2000, 65, 1.

[10] Lokhande C., Ennaoui A., Patil P. et al.: Thin Solid Films, 1999, 340, 18.

[11] Barreau N., Marsillac S., Albertini D. and Bemmede J.: Thin Solid Films, 2002, 403-404, 331.

[12] Calixto-Rodriguez M., Tiburcio-Silver A., Ortiz A. and Sanchez-Juarez A.: Thin Solid Films, 2005, 480-481, 133.

\section{ПОРІВНЯЛЬНІ ДОСЛІДЖЕННЯ ФІЗИКО- ХІМІЧНИХ ВЛАСТИВОСТЕЙ СУЛЬФІДНИХ ПЛІВОК ІНДІЮ, ХІМІЧНО ОСАДЖЕНИХ ЗА РІЗНИХ УМОВ}

\begin{abstract}
Анотація. Сульфідні плівки індію хімічно осаджені на скло та скло, покрите індій-олово оксидом (ІТО). Вивчено вплив різних параметрів осадження, а саме вплив природи підкладки $i$ pH середовища. Кристалічну будову, морфологію поверхні $i$ складу отриманих плівок охарактеризовано за допомогою рентгенівської дифракції, скануючої електронної мікроскопії, енергодисперсійної спектроскопї та оптичної абсорбиії. Аморфний характер плівок підтверджений рентгенівськими дослідженнями. 3 використанням скануючої електронноі мікроскопї доведено випадкову орієнтаиію осаджених індійсульфідних плівок на ITO-склі, тоді як плівки, осаджені на скляні підкладки, мають форму гантелей. Дослідження оптичного поглинання показало, щчо для висадженої плівки ширина забороненої зони змінюється від 2,29 до 2,79 еВ.
\end{abstract}

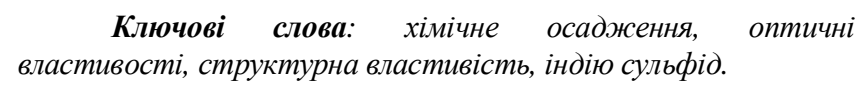

